\title{
Wetland Habitat Diversity in the Amazonian Piedmont of Colombia
}

\section{Journal Article}

\section{Author(s):}

Ricaurte, Luisa Fernanda; Jokela, Jukka (iD; Siqueira, Auberto; Núñez-Avellaneda, Marcela; Marin, Cesar; Velázquez-Valencia, Alexander; Wantzen, Karl Matthias

Publication date:

2012-12

\section{Permanent link:}

https://doi.org/10.3929/ethz-b-000059657

\section{Rights / license:}

In Copyright - Non-Commercial Use Permitted

\section{Originally published in:}

Wetlands 32(6), https://doi.org/10.1007/s13157-012-0348-y 


\title{
Wetland Habitat Diversity in the Amazonian Piedmont of Colombia
}

\author{
Luisa Fernanda Ricaurte • Jukka Jokela • Auberto Siqueira • \\ Marcela Núñez-Avellaneda • Cesar Marin • \\ Alexander Velázquez-Valencia • Karl Matthias Wantzen
}

Received: 20 April 2012 / Accepted: 22 October 2012 / Published online: 2 November 2012

(C) Society of Wetland Scientists 2012

\begin{abstract}
Management of wetlands is often constrained by lack of a precise typology of habitats. Regional landscape attributes need to be considered in the integrative research of wetlands to allow habitat-specific management. Here we investigated the distribution and the habitat diversity of the wetlands in the Amazonian Piedmont in the Caquetá Department of Colombia. Based on the landscape approach we combined geomorphic, hydro-chemical and biotic attributes. We used remote sensing based interpretation and ground truth verification. We found 896 wetlands covering up to $11 \%$ of the study area. Our estimate of the wetland area does not reflect the true historic wetland area (occasionally flooded area) because $76.9 \%$ of the flooded active floodplain area has been converted to pastures. Including the pastures the estimated wetland area is $29.3 \%$ of the study region. We identified 7 wetland habitats. The method we applied can be used to map small and middle sized wetlands achieving an acceptable overall accuracy. These wetlands provide important ecosystem services and act as corridors
\end{abstract}

L. F. Ricaurte $(\bowtie) \cdot$ J. Jokela

Department of Aquatic Ecology, EAWAG, Swiss Federal Institute

of Aquatic Sciences and Technology,

Duebendorf, Switzerland

e-mail: ricaurte.luisa@gmail.com

L. F. Ricaurte $\cdot$ J. Jokela

IBZ, Institute of Integrative Biology,

ETH-Zürich, Switzerland

\section{A. Siqueira}

Faculdade de Arquitetura, Engenharia e Tecnologia, Departamento de Engenharia Elétrica, Universidade Federal de Mato Grosso,

Av. Fernando Correa da Costa, S/N,

78060-900 Cuiabá, Brazil

M. Núñez-Avellaneda

Instituto Amazónico de Investigaciones Científicas (SINCHI),

Avenida Vásquez Cobo entre calles 15 y 16,

Leticia, Colombia for biodiversity in human-dominated landscapes such as the Caquetá region. Our results provide support for the wise use of tropical wetlands and may help to improve landscape management in the Amazon basin.

Keywords Aquatic habitat - Conservation - Landscape . South America $\cdot$ Sustainable management $\cdot$ Wetland classification

\section{Introduction}

Lack of knowledge has been identified as one of the main drivers of wetland destruction and an important obstacle in restoration (Adger and Luttrell 2000; Gopal 2005). For example, environmental information on the wetlands in the Amazon region is scarce (Junk and Piedade 2004), and only the Directory of Neotropical Wetlands (Scott and Carbonell 1986) and its update (Canevari et al. 2001) are currently

\section{Marin}

Escuela de Biología, Universidad Industrial de Santander-UIS, Facultad de Ciencias,

Bucaramanga, Colombia

A. Velázquez-Valencia

Museo de Historia Natural, Universidad de la Amazonia, Florencia, Colombia

K. M. Wantzen

Interdisciplinary Research Center for Cities, Territories,

Environment and Society (CITERES-CNRS UMR 7324),

Université François Rabelais,

Parc Grandmont,

37200 Tours, France 
available at the continental level. Previous wetland inventories in countries bordering the Amazonian catchment remain unpublished and are not widely cited (Naranjo 1995; Duque et al. 1997; Diegues 2002; Maltchik 2003), although wetland inventories and classifications aim at reducing this knowledge gap. Different wetland classification systems have been proposed and the preference for their application varies regionally (e.g., Cowardin et al. 1979; Scott 1989; Brinson 1993; Semeniuk and Semeniuk 1995; Neiff 2001; Brinson and Malvárez 2002). Among a wide range of regional classification systems for wetlands, the system for Amazonian lowland wetlands, developed by Junk and Piedade (2005) and refined by Junk et al. (2011) is the system that corresponds most closely to the western Amazonian Piedmont region.

In the last decades wetlands have received increasing attention by environmental policy makers, managers and scientists. At present, several wetland definitions exist to fulfill biological, jurisdictional or environmental protection purposes (Mitsch and Gosselink 2007). Essentially, wetlands are areas where the hydrology is the primary factor controlling the environment and associated biodiversity (Cowardin et al. 1979). Wetlands are well recognized for their supporting and regulating functions for biodiversity, hydrology and climate (Zedler and Kercher 2005; Mitsch and Gosselink 2007), and for providing key livelihood for local people, making them irreplaceable for regional economies (Maltby 2009). However, due to their ecological and socioeconomic importance, they are areas of high environmental conflict and pressure (Turner et al. 2000) and are among the most threatened ecosystems on earth (Ramsar 2006). Restoration of wetlands and reversal of wetland loss is one of the key environmental challenges today (Junk 2002; Polunin et al. 2008).

We chose the Amazonian Piedmont region for our study due to its diversity and the urgent necessity to deliver baseline data for sound environmental management. It is a transitional zone between the Andes and the Amazon rainforest, at an altitude from 300 to $1,000 \mathrm{~m}$ asl. It belongs to the Western Amazon Piedmont freshwater ecoregion (Abell et al. 2008) and is characterized by a high biodiversity (Prance 1982; Gentry 1992; Zuluaga 2008). Therefore it is known as a "biodiversity hotspot" (Myers et al. 2000; Etter et al. 2006b). In spite of these values, the natural land cover in the Caquetá Department in Colombia has been intensively fragmented since the 1950's due to land conversion for agriculture and cattle ranching (Arcila-Niño et al. 2000; Gutierrez-Rey et al. 2003). Today, the traditional land use has dramatically changed towards large-scale urban, mining and agricultural development projects (Gutierrez-Rey et al. 2003; Etter et al. 2006c; Malhi et al. 2008). With increasing human population and ongoing economic growth (Millenium Ecosystem Assessment 2005), remnant wetlands in such human-dominated landscape face an uncertain future.
In this paper we deliver the first estimates on the distribution and habitat diversity of the wetlands in the Amazonian Piedmont in the Caquetá Department of Colombia. The study, including different methods of remote sensing and ground truth analysis was based on a landscape ecology approach (Wiens 2002). Thus, wetlands were considered as individual patches of landforms that are embedded into larger, relatively homogeneous units (Amoros and Petts 1993; Brinson 1993; Bedford 1996), which we homologize with physiographic units (Villota 1992). The physiographic units provide an integrative view about the hydrology, geology, relief, soils and land cover features that might form wetlands (Bedford 1996). To delineate wetlands we combined geomorphic (landforms), hydro-chemical (hydrological regime and water type) and biotic (dominant vegetation) attributes, thus allowing us to focus on analysis of "active wetlands". We define active wetlands as landforms saturated with water which support the typical vegetation adapted for life in saturated soil conditions and are embedded within highly anthropogenic landscapes.

We will show that there is a high density of small and middle sized wetlands in the Amazon Piedmont of Colombia, making them a priority for future research and focal conservation targets. There is an urgent need of reconciling the human use and conservation of the biodiversity of these wetlands. The overarching goal of this study is therefore to deliver a scientific baseline for habitat restoration and sustainable management of these wetlands.

\section{Methods}

\section{Study Area}

The study area covers 242,624 ha located in the upper basin of the Orteguaza River at the Amazonian Piedmont to the Northwest of the Amazon Basin in Colombia $\left(6^{\circ} 0^{\prime} \mathrm{N}-72^{\circ}\right.$ $15^{\prime} \mathrm{W}$, and $5^{\circ} 45^{\prime} \mathrm{N}-72^{\circ} 00^{\prime} \mathrm{W}$ ). The prevailing climate is warm-humid (Caldas-Land Climate Classification, Eslava et al. 1986), with an average annual temperature of $25.3{ }^{\circ} \mathrm{C}$ and an average humidity of $85 \%$. The average annual rainfall is about 3,900 mm, $50 \%$ of which falls from March to July, which corresponds to the wet season. In the dry season, between December and January, rainfall is below $200 \mathrm{~mm}$ per month (IDEAM 2011). This monomodal rainfall pattern, which is affected by the Intertropical Convergence Zone (ITCZ), causes high river levels and overflows in the lowland floodplains during the rainy season, whereas the water volume decreases significantly during the dry season (Junk et al. 1989) (Fig. 1). The Orteguaza River is a ninth-order stream, with a total length of $200 \mathrm{~km}$ and a discharge that ranges from 62.8 to $666.4 \mathrm{~m}^{3} \mathrm{~s}^{-1}$, with a runoff coefficient of 0.75 (IDEAM 2011) (Fig. 2). It 

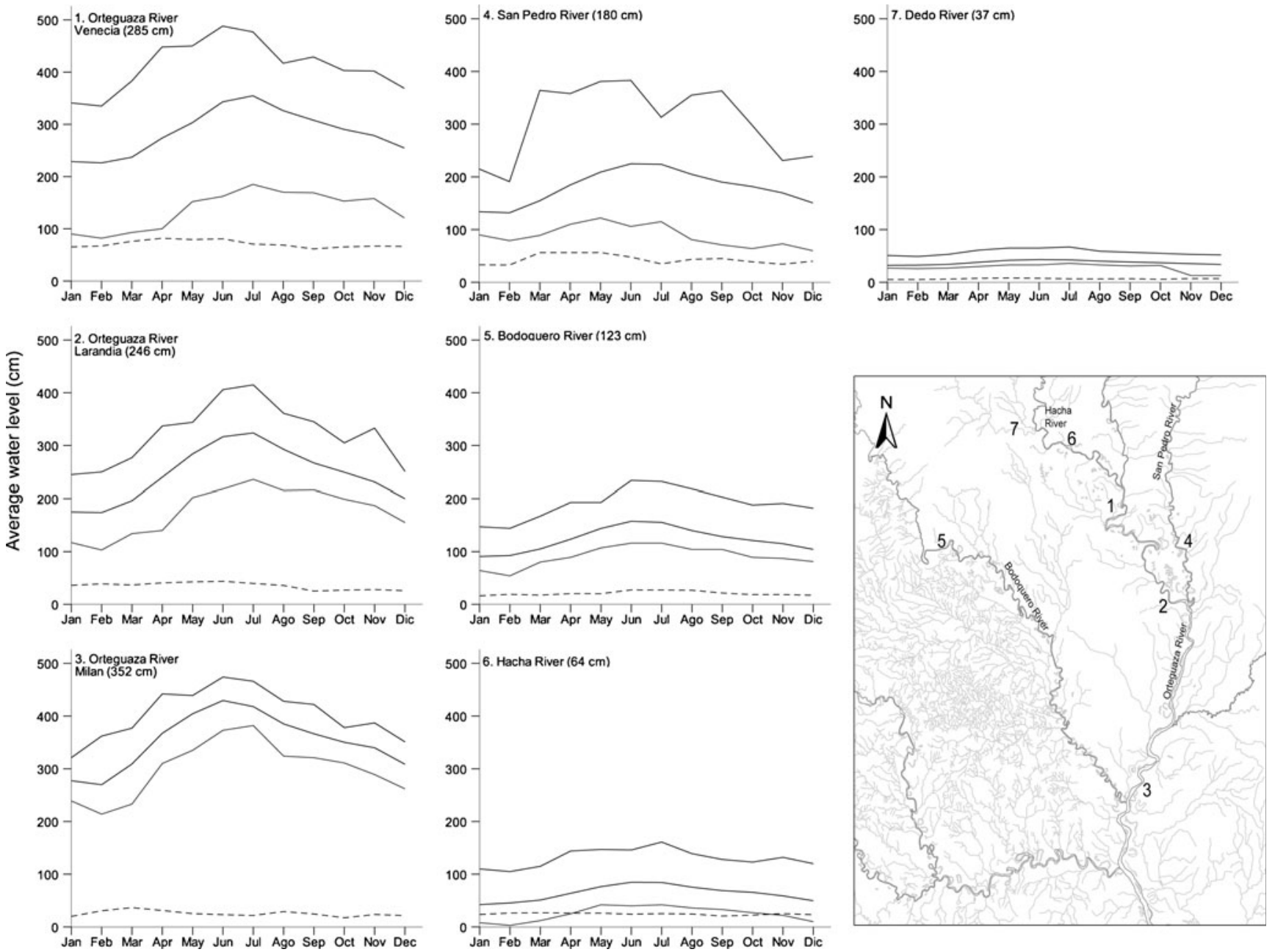

Fig. 1 Hydrographs for the Orteguaza, San Pedro, Bodoquero, Hacha and Dedo Rivers, from 1971 to 2010 (except station 3, from 1988 to 2010). From top to bottom, the curves indicate the yearly maximum, average, minimum and standard deviation based on monthly average

receives the Pescado, Bodoquero, Fragua Chorroso Rivers (eighth-order streams), the Hacha River (seventh-order stream) and the San Pedro River (sixth-order stream) (Strahler 1952). Moreover, the area has a high density of first and second order streams.

At the scale of 1:100,000 there are two principal physiographic units (IGAC 1999, Etter et al. 2006a): (i) the Andean fluvial deposits along streams of higher order $(23.8 \%$ of the study area), which includes both the frequently flooded active floodplains and the mainly dry but occasionally flooded floodplains at a time of high water periods, which are still considered "active" by hydrologists (Leopold et al. 1964; Junk et al. 1989), and (ii) the interfluves, formed by the foothills and hillslopes ( $76.2 \%$ of the study area) (Fig. 3). In this area, tectonic and volcanic activities may locally change the course of the rivers. From West to East, river channel structure changes from anastomosing bedrock and gravel-bedded channels to meandering and braided sand channels (Mertes and water level values. Numbers in $\mathrm{cm}$ indicate the average water level. Location of the stations is showed on the map (data: Sistema de Información Nacional Ambiental, Instituto de Hidrología, Meteorología y Estudios Ambientales IDEAM)

Dunne 2008). The active river floodplains are characterized by small and middle-sized aquatic-terrestrial transition zones (ATTZ) of up to $9 \mathrm{~km}$ in width. These alluvial overflow plains are flat and convex, corresponding to natural levees. They alternate locally with more elevated areas of rectilinear and rectangular drainage patterns. These drainage areas have structural and depositional control with low terraces $(2-5 \mathrm{~m})$ and with flat-concave, flat-convex areas with slopes $<3 \%$ and high sediment accumulation. Soils that are present are finemiddle textured, slow-imperfect drained and highly acid with low-moderate fertility (IGAC 1999). In the interfluves the landscape is rolling and undulated with irregular slopes (30$80 \mathrm{~m}, 7-25 \%)$ and interspersed by small and narrow Vshaped valleys with flat bottoms. The lower parts of this undulated landscape may be subject to periodic flooding. While erosion due to water in naturally covered areas is moderate, erosion by livestock grazing and trampling is strong in artificial pastures. Soils are characterized by medium to 

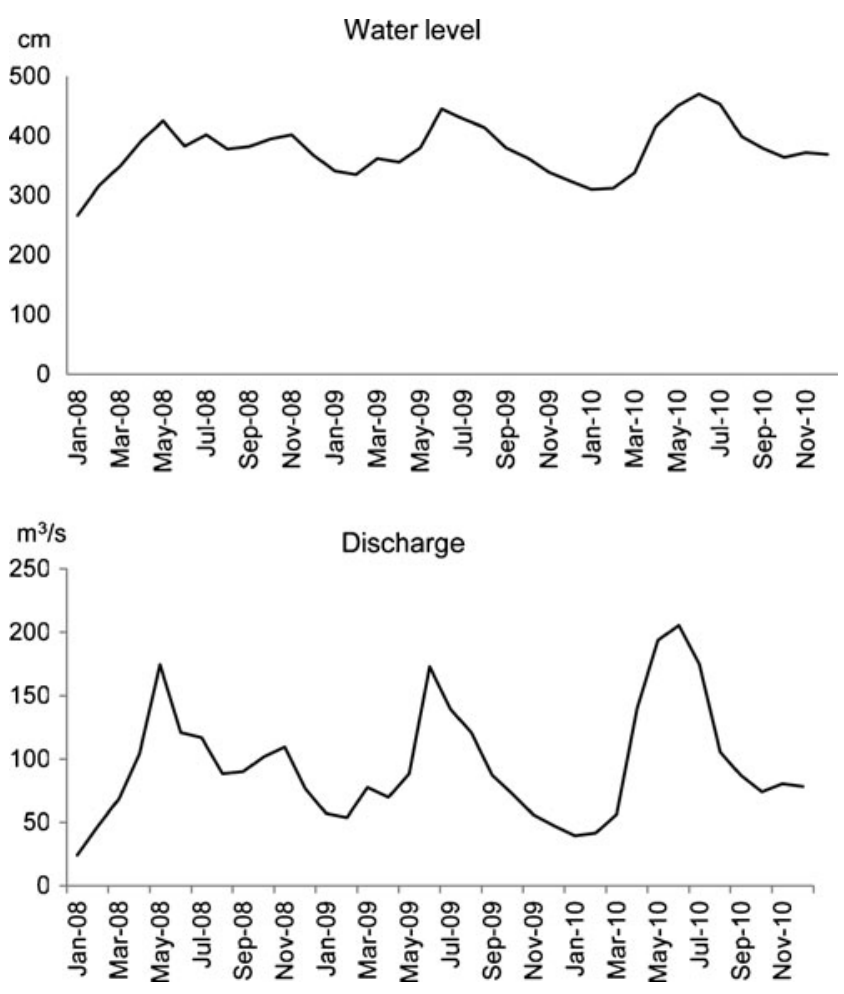

Fig. 2 Estimated water level and discharge curves of 3 years - from 2008 to 2010 - showing frequent ups and downs for the Orteguaza River. Curves were estimated from monthly average values (data: Sistema de Información Nacional Ambiental, Instituto de Hidrología, Meteorología y Estudios Ambientales IDEAM)

moderate deep, coarse texture, rapid drainage, high acidity, and low to moderate fertility. The entire area is covered by Upper Tertiary and Lower Quaternary lacustrine and glacial deposits of clays, silt and sandstones (IGAC 1999).

\section{Data Sets}

Two Landsat satellite images were obtained from the Global Land Cover Facility of the University of Maryland (GLFC, http:/glcf.umiacs.umd.edu/index.shtml) to produce the physiographic and wetland maps. Cloud-free images (less than $10 \%$ ) were available that visually revealed seasonal differences for discriminating water and vegetation categories for the two hydrological periods: (i) low-water: TM 8-59 from December 1989 (mean water level $244 \mathrm{~cm}$, IDEAM 2011) and (ii) fallingwater: ETM + 8-59 from October 2002 (mean water level $403 \mathrm{~cm}$, IDEAM 2011), with a pixel resolution of $30 \times 30 \mathrm{~m}$ (Table 1). To improve the images for visual interpretation, contrast (histogram equalization) and spatial enhancement (high pass filters) techniques were applied. Additionally, we calculated the Optimum Index Factor (OIF), to choose the best combination of three bands in each satellite image and create the optimal false color composites. As a result, we obtained two composites: 453 (RGB) and 457 (RGB). Both composites showed good results for visually discriminating the wetlands from the surrounding landscape, because the infrared bands red (band 3), near-IR (band 4) and mid-IR (bands 5 and 7) highlight the land-water boundaries with great precision due to the strong absorption capabilities of water (Frazier and Page 2000; Jensen 2000; Hui et al. 2008). With these band composites the vegetation shows a variation of greens, oranges and browns, and the water appears as the darkest tones.

Using bridges, villages and cross sections of roads (obtained from base maps No. 432/1985, No. 433/1988, 413-414/1998) as control points, the images were georeferenced with a maximum mean-error (RME) of 0.1 pixels. Additionally the SRTM $90 \mathrm{~m}$ digital elevation model obtained from the CGIAR-CSI Consortium for Spatial Information (http://srtm.csi.cgiar.org/) was integrated into the data set. Based on it, we calculated the order of the streams (Strahler 1952) by using ArcGis Spatial Analyst 10.0 (ESRI 2011). We also used existing ancillary data on geology, relief, soils, hydrology, and land cover (IGAC 1979; Saldarriaga and van der Hammen 1993; IGAC 1999; IDEAM 2011) (Table 1).

All GIS data were projected using the International 1924 Ellipsoid with the Bogotá Datum. Digital image processing and general mapping was undertaken using ILWIS 3.1 (ITCILWIS 2005) and ArcGIS 10 (ESRI 2011). All data were analyzed using SPSS (ver. 17).

\section{Wetland Mapping}

In this process we used the visual interpretation technique based on tone/color, shape, texture and spatial pattern elements of the satellite images (Jensen 2000) thereby avoiding some classification problems experienced with 30-meter satellite images. This allowed us to delineate wetlands of small size and to classify accurately the land cover to their interior. To produce the wetland map we conducted the following steps:

a. The physiographic units comprising the study area were mapped at a scale of 1:100,000 using the 457 (RGB) false color composite from Landsat image 859/ 2002 and ancillary reference data (Table 1): (i) the Andean fluvial deposits along higher order streams forming the active floodplains, and (ii) the interfluves consisting of foothills and hillslopes;

b. The individual landforms where the wetlands occur were delineated including: V-shape valleys, oxbows, islands, and meander scroll bars. The topography of the meander scroll bars, characterized by ridges and swales (Charlton 2008), allows the formation of lakes that are partially interconnected; thus, in this study this landform is referred to as wetland complexes, and the oxbows as lakes. The V-shape valleys in the interfluves were assigned as marshes or riparian wetlands. The contours of the water bodies were digitized from 


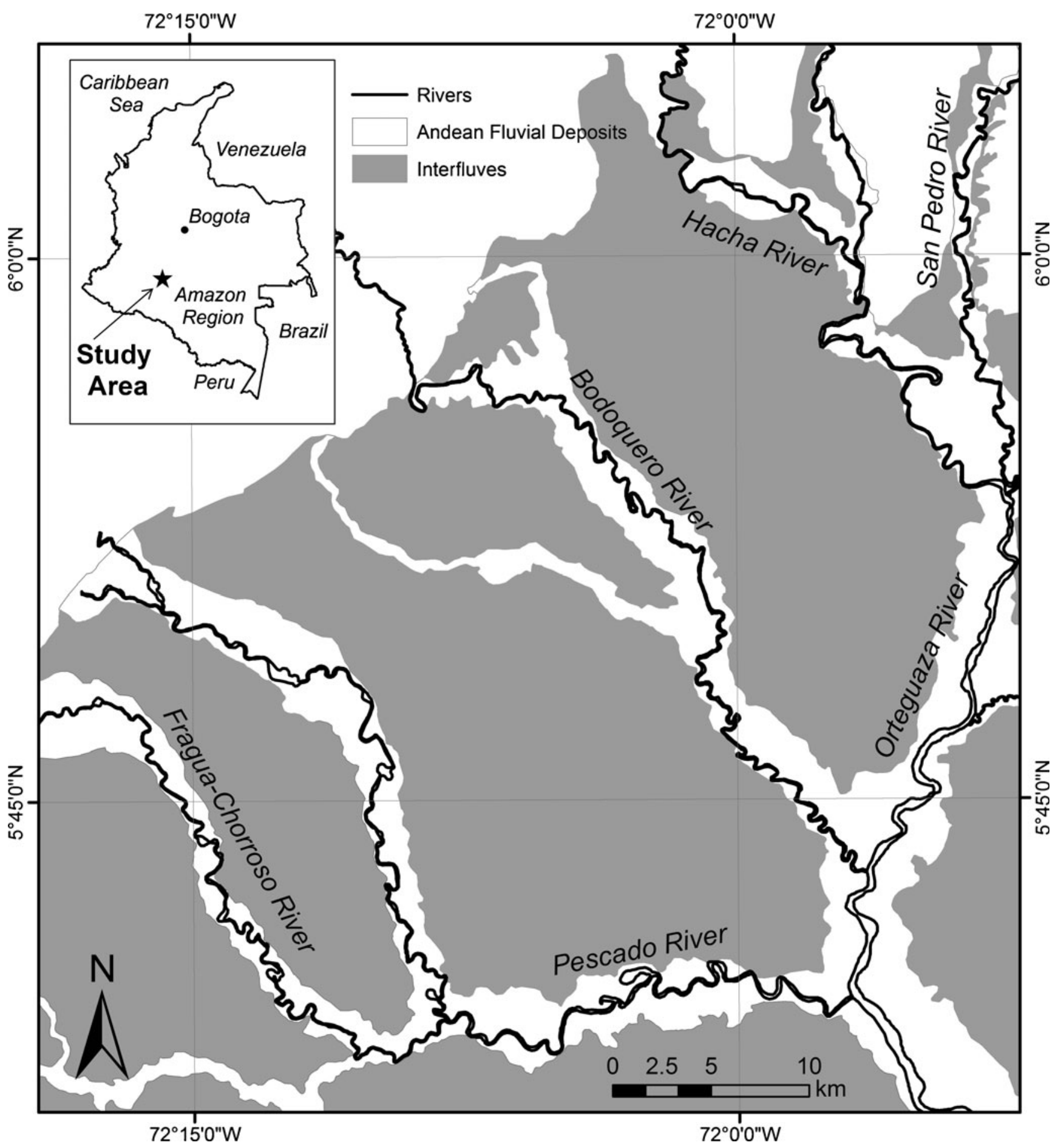

Fig. 3 Map showing the major rivers (6th and higher order streams) and the two principal physiographic units that form the landscape at the Orteguaza River catchment

453 (RGB) color composite from Landsat image 859/ 2002 (falling-water);

c. Assignment of the mapped water bodies to wetland classes by means of hydro-chemical and vegetation attributes:

- The hydrological regime was divided into permanently and periodically waterlogged classes according to Junk et al. (2011). The classes were determined by multi-temporal visual interpretation using the two sets of the 453 (RGB) color composite of the Landsat images from 1989 (low-water) and from 2002 (falling-water). When the same water body appeared dark (water-covered) in both images, then it was classified as permanently waterlogged. Water bodies presenting a dark area during one of the images and a clear area 
Table 1 Data sources analyzed in the present study

\begin{tabular}{|c|c|c|c|}
\hline Year & Type & Spatial scale & Institution \\
\hline 1985 & $\begin{array}{l}\text { Base map No. 432. Fragua Chorroso, } \\
\text { Pescado, Bodoquero Rivers. }\end{array}$ & $1: 100,000$ & Instituto Geográfico Agustín Codazzi IGAC. \\
\hline 1988 & $\begin{array}{l}\text { Base map No. 433. Orteguaza, } \\
\text { Bodoquero, Pescado, Penaya Rivers. }\end{array}$ & $1: 100,000$ & Instituto Geográfico Agustín Codazzi IGAC. \\
\hline 1998 & $\begin{array}{l}\text { Base map No. 413. Pescado, Bodoquero, } \\
\text { Hacha Rivers. }\end{array}$ & $1: 100,000$ & Instituto Geográfico Agustín Codazzi IGAC. \\
\hline 1998 & $\begin{array}{l}\text { Base map No. 414. Orteguaza, Hacha, } \\
\text { San Pedro Rivers. }\end{array}$ & $1: 100,000$ & Instituto Geográfico Agustín Codazzi IGAC. \\
\hline 1979 & Thematic maps PRORADAM Project. & $1: 500,000$ & Instituto Geográfico Agustín Codazzi IGAC. \\
\hline 1993 & Thematic maps. & $1: 250,000$ & $\begin{array}{l}\text { Instituto Geográfico Agustín Codazzi IGAC, } \\
\text { Fundación Tropenbos. }\end{array}$ \\
\hline 1998 & Thematic maps ORAM Project. & $1: 750,000$ & Instituto Geográfico Agustín Codazzi IGAC. \\
\hline 1989 & $\begin{array}{l}\text { Landsat TM, ID: 032-359, 008/059, } \\
\text { Acq. Date: } 1989-12-22 .\end{array}$ & $30 \mathrm{~m}$ pixel & $\begin{array}{l}\text { Global Land Cover Facility of the University of Maryland, } \\
\text { GLFC, http://glcf.umiacs.umd.edu/index.shtml. }\end{array}$ \\
\hline 2002 & $\begin{array}{l}\text { Landsat ETM+, ID: } 018-217,008 / 059 \text {, } \\
\text { Acq. Date: } 2002-10-07 .\end{array}$ & $30 \mathrm{~m}$ pixel & $\begin{array}{l}\text { Global Land Cover Facility of the University of Maryland, } \\
\text { GLFC, http://glcf.umiacs.umd.edu/index.shtml. }\end{array}$ \\
\hline 2011 & $\begin{array}{l}\text { SRTM digital elevation model, } \\
\text { last access date: } 2011 .\end{array}$ & $90 \mathrm{~m}$ resolution & $\begin{array}{l}\text { CGIAR-CSI Consortium for Spatial Information } \\
\text { (http://srtm.csi.cgiar.org/). }\end{array}$ \\
\hline 1971-2010 & Climate and hydrologic data. & & $\begin{array}{l}\text { Sistema de Información Nacional Ambiental, } \\
\text { Instituto de hidrología, meteorología y estudios ambientales, IDEAM. }\end{array}$ \\
\hline
\end{tabular}

during the other were classified as periodically waterlogged. These first attributions were confirmed by local climatic and hydrologic data.

- The water type was classified as white, black, or clear according to the existing classification system for the Amazonian waters (Sioli 1950; Junk and Furch 1985). White water is turbid with a high concentration of suspended silt solids, has low transparency (Secchi disk depth: 20-60 cm) and $\mathrm{pH}$ is near neutral. Black water is also turbid, brownish with middle transparency $(60-120 \mathrm{~cm})$ and $\mathrm{pH}$ ranging from 3.7 to 4.9 . Clear water is green to olive-green, very transparent $(>150 \mathrm{~cm}$ ), and $\mathrm{pH}$ ranges from 5 to 8 (Sioli 1984; Junk et al. 2011). Here, we assigned clear water for the rivers of Andean origin (6th and higher order streams) and black water for the lower-order streams of Amazon origin and for other isolated wetlands.

- The predominant vegetation physiognomy prevailing at the interior area of the wetland was attributed to: (i) grassy shrub areas (further referred to as marshes) and (ii) woody areas (referred to as swamps), according to Mitsch et al. (2009). For this purpose, the 453 (RGB) false color composite from 2002 was visually interpreted based on shape, texture, tone/color and pattern elements.

d. Establishment of the classes for the classification of the major wetland habitats based on the previous attributes:

- V-shape valley + periodically waterlogged + black water + grassy shrub vegetation: interfluvial grassy shrub marsh (M),
- V-shape valley + permanently waterlogged + black water + woody vegetation: riparian wetland (RW),

- Meander scroll bars + periodically waterlogged + black water + grassy shrub vegetation: periodically waterlogged grassy shrub wetland complex (CG),

- Meander scroll bars + permanently waterlogged + black water + woody vegetation: permanently waterlogged woody wetland complex $(\mathrm{CW})$,

- Oxbow + permanently waterlogged + black water + grassy shrub vegetation: permanently waterlogged grassy shrub oxbow lake (OG),

- Oxbow + permanently waterlogged + black water + woody vegetation: permanently waterlogged woody oxbow lake (OW),

- Island + periodically waterlogged + black water + grassy shrub vegetation: periodically waterlogged grassy shrub marsh on islands (MI).

\section{Assessment of Accuracy of the Classification}

We performed two field trips to assess the accuracy of the wetland habitat classification. In November 2002, corresponding to dry season and decreasing water regime, we sampled the vegetation structure and water chemistry in 18 wetlands that were selected based on a stratified random sampling design. The vegetation samples were collected in areas that represented natural state covering several successional stages. We described the vegetation cover and understory including the most conspicuous aspects such as large dominant species, general plant height and density of the entire wetland area. Further analyses to 
establish the dominant floristic classes, based on the floristic composition and species abundance (Bray and Curtis 1957; Odum 1983; Duivenvoorden 1996) were performed. Water was sampled to define the predominant water type based on physical and chemical parameters (concentration of dissolved solids, oxygen concentration, $\mathrm{pH}$ and transparency). These 18 wetlands were used in the initial wetland classification.

In March 2012, a much larger additional stratified random sample of 118 wetlands was visited for further validation of the wetland classification. This sample corresponded to $13.2 \%$ of total number of mapped wetlands $(N=896)$. Six of these wetlands were included in the sample of 18 wetlands that were sampled previously in year 2002 .

Based on estimates provided by Meidinger (2000) for the approximate minimum sample sizes for map accuracy assessment, the sample from 2012 was considered to be sufficient to estimate the accuracy of wetland classification with $95 \%$ confidence and $4 \%$ maximum error. An error matrix was constructed to compare classified data with the reference data, and overall accuracy, producer accuracy, user accuracy (Story and Congalton 1986; Congalton 1991; Carle 2011), and Kappa statistic (Congalton 1991, 2001) were calculated. Overall map accuracy was calculated by dividing the total number of correctly classified polygons by the total number of reference polygons in the error matrix, and accuracy of the individual habitat classes was measured by calculating the producer's accuracy (errors of omission) and user's accuracy (errors of commission) (Story and Congalton 1986). Kappa (k-hat) is another multivariate technique to assess the accuracy (Congalton 1991). The K-hat coefficient (Bishop et al. 1975) measures the difference between the observed agreement and the agreement expected by chance (Congalton 1991). It ranges from 1 to -1 with one representing perfect agreement and with minus one representing no agreement among the classified and reference data. Additionally, we calculated the $95 \%$ confidence intervals for each producer and user statistics according to the formula (Carle 2011):

$C I=1.96 * 100 * \operatorname{SQRT}\left(\left(\frac{n}{100} * \frac{100-n}{100}\right) / N\right)$

where $n$ is the accuracy of the individual habitat classes and $N$ is the total number of the reference polygons for each habitat class. For comparison, we calculated the producer and user accuracy, Kappa and confidence intervals also for the smaller sample of 2002 (Table 2).

We suspected that the assessment based on the sample from 2012 might have suffered from errors that were due to change in the wetland type that was either natural or human caused as there was 10 years between the actual classification (year 2002) and ground validation (year 2012). To evaluate such bias one would need to know which wetland types were most likely affected by natural succession or human activities. To achieve this, we compared the classification results of those six wetlands which were visited in both 2002 and 2012, as any difference in classification for these wetlands would result from natural successional process or human activities. This comparison, although based on a small sample, helps in identifying which wetland types were most likely to change by human activities or natural succession over the 10 year time period.

\section{Results}

Assessment of Accuracy of the Wetland Classification

When the sample of 2012 was used to evaluate the accuracy of classification, we found that the overall accuracy was $62.7 \%$ (95\% CI= \pm 8.7 ) with a K-hat coefficient of 0.48 (Table 2). When we used the 18 wetlands that were sampled in 2002 the overall accuracy was higher: $77.8 \%(95 \% \mathrm{CI}= \pm 19.2)$ and $\mathrm{K}$ hat coefficient of 0.72 , although the sample size was small. When we compared the wetland class of those wetlands that were visited in both 2002 and $2012(N=6)$ we found that four of them had changed status and two remained the same. Those that changed were either grassy marshes that had become forested and classified now as riparian wetlands $(N=2)$ or riparian wetlands that were deforested by human activities $(N=2)$.

For the 2012 accuracy assessment, permanently waterlogged grassy shrub oxbow lakes (OG) had the highest producer and user accuracy $(100 \%)$. For the producer accuracy, periodically waterlogged grassy shrub wetland complexes (CG) and permanently waterlogged woody wetland complexes $(\mathrm{CW})$ presented the highest measure (100\%), with lower values for the periodically waterlogged grassy shrub marshes on islands (MI) $(84.6 \%)$ and the permanently waterlogged woody oxbow lakes (OW) (50\%). Low measures for producer and user accuracy indicate that riparian wetlands (RW) and interfluvial grassy shrub marshes (M) were the most often confused among themselves (riparian wetlands: $56.5 \%, 79.55 \%$; interfluvial grassy shrub marshes: $59.1 \%, 32.5 \%$, respectively). Such a disagreement was produced by changes in the vegetative cover, deforestation or regeneration, as was expected given the time difference between both sample periods (10 years). In addition, user accuracy indicates that permanently waterlogged woody oxbow lakes $(\mathrm{OW})$ and the periodically waterlogged grassy shrub marshes on islands (MI) were rarely confused (100\% and $78.6 \%$, respectively). The last wetland habitats, the periodically waterlogged grassy shrub wetland complexes (CG) and the permanently waterlogged woody wetland complexes (CW) had low user accuracy (33.3\% and $50 \%$, respectively).

\section{Distribution of Wetland Habitats}

The final wetland map (Fig. 4) presents the distribution of the well discernible wetland habitats for the Orteguaza River catchment, accounting for a total of 896 active wetlands. These cover 26,485 ha, with minimum and maximum wetland 
Table 2 Two error matrices calculated for the classification of the wetland habitats at the Orteguaza River catchment. First matrix shows the accuracy based on the sample of year 2002. Second matrix presents the accuracy based on the sample of wetlands 10 years later in 2012, which included some transitions that most likely took place due to natural biological succession or due to anthropogenic change (see text). Numbers in bold indicate correct classifications. Abbreviations: $\mathrm{M}=$
Interfluvial grassy shrub marshes, RW = Riparian wetlands, $\mathrm{CG}=$ Periodically waterlogged grassy shrub wetland complexes, $\mathrm{CW}=$ Permanently waterlogged woody wetland complexes, OG $=$ Permanently waterlogged grassy shrub oxbow lakes, OW $=$ Permanently waterlogged woody oxbow lakes, MI $=$ Periodically waterlogged grassy shrub marshes on islands, PA = Producers Accuracy, UA = Users Accuracy, $\mathrm{CI}=$ Confidence Interval

\begin{tabular}{|c|c|c|c|c|c|c|c|c|c|c|c|c|c|c|}
\hline \multirow{4}{*}{$\begin{array}{l}\text { Classified } \\
\text { data }\end{array}$} & & \multicolumn{8}{|c|}{2002 Reference data $(n=18)$} & \multicolumn{2}{|l|}{ PA } & \multicolumn{3}{|l|}{ UA } \\
\hline & & M & RW & CG & $\mathrm{CW}$ & OG & OW & MI & Total & $\mathrm{PA} \%$ & $95 \% \mathrm{CI} \pm$ & $\mathrm{UA} \%$ & $95 \% \mathrm{CI} \pm$ & \\
\hline & M & 1 & & & & & & & 1 & 100 & 0 & 100 & 0 & \\
\hline & RW & & 7 & & & & & & 7 & 100 & 0 & 100 & 0 & $\begin{array}{l}\text { Total } \\
\text { accuracy= } \\
77.8 \%\end{array}$ \\
\hline \multirow{16}{*}{$\begin{array}{l}\text { Classified } \\
\text { data }\end{array}$} & CG & & & 1 & 2 & & & & 3 & 100 & 0 & 33.3 & 53.3 & K-hat $=0.72$ \\
\hline & $\mathrm{CW}$ & & & & 1 & & & & 1 & 33.3 & 53.3 & 100 & 0 & Overall $95 \%$ \\
\hline & OG & & & & & 2 & 1 & & 3 & 66.6 & 53.3 & 66.6 & 53.3 & $\mathrm{CI}= \pm 19.2$ \\
\hline & OW & & & & & 1 & 1 & & 2 & 50 & 69.9 & 50 & 69.3 & \\
\hline & MI & & & & & & & 1 & 1 & 100 & 0 & 100 & 0 & \\
\hline & Total & 1 & 7 & 1 & 3 & 3 & 2 & 1 & 18 & & & & & \\
\hline & & \multicolumn{8}{|c|}{2012 Reference data $(n=118)$} & PA & & \multicolumn{3}{|l|}{ UA } \\
\hline & & M & RW & CG & $\mathrm{CW}$ & OG & OW & MI & Total & $\mathrm{PA} \%$ & $95 \% \mathrm{CI}$ & $\mathrm{UA} \%$ & $95 \% \mathrm{CI} \pm$ & \\
\hline & M & 13 & 26 & & & & 1 & & 40 & 59.1 & 25.5 & 32.5 & 14.5 & \\
\hline & RW & 9 & 35 & & & & & & 44 & 56.5 & 12.3 & 79.5 & 12 & $\begin{array}{l}\text { Total } \\
\text { accuracy= } \\
62.7 \%\end{array}$ \\
\hline & CG & & & 2 & & & 2 & 2 & 6 & 100 & 0 & 33.3 & 37.7 & $\mathrm{~K}-\mathrm{hat}=0.48$ \\
\hline & $\mathrm{CW}$ & & 1 & & 1 & & & & 2 & 100 & 0 & 50 & 70 & Overall $95 \%$ \\
\hline & OG & & & & & 6 & & & 6 & 100 & 0 & 100 & 0 & $\mathrm{CI}= \pm 8.7$ \\
\hline & OW & & & & & & 6 & & 6 & 50 & 28.3 & 100 & 0 & \\
\hline & MI & & & & & & 3 & 11 & 14 & 84.6 & 19.6 & 78.6 & 21.5 & \\
\hline & Total & 22 & 62 & 2 & 1 & 6 & 12 & 13 & 118 & & & & & \\
\hline
\end{tabular}

sizes of approximately 0.37 ha and 2,399 ha, respectively. Riparian wetlands (RW) represented the most abundant habitat with an estimated $35.2 \%$ (7,180 ha) of the total wetland cover, followed by interfluvial grassy shrub marshes (M) $26.6 \%(5,969 \mathrm{ha})$, periodically waterlogged grassy shrub marshes on islands (MI) $14.4 \%$ (547 ha), periodically waterlogged grassy shrub wetland complexes (CG) $7.5 \%$ (6,541 ha), permanently waterlogged grassy shrub oxbow lakes (OG) $6.5 \%$ (597 ha), permanently waterlogged woody oxbow lakes (OW) $6.1 \%$ (452 ha) and permanently waterlogged woody wetland complexes (CW) $3.8 \%$ (5,199 ha) (Table 3).

In relation to the physiographic units, wetland distribution had a larger concentration of wetlands in the river floodplains compared to the interfluves. The entire study area $(242,624 \mathrm{ha})$ was comprised of $23.8 \%$ river floodplains $(57,777$ ha) and $76.2 \%$ of interfluves (184,847 ha). In the river floodplain area we found 13,336 ha of active wetlands and they covered $23.1 \%$ of the entire floodplain. The remaining floodplain area $(44,441 \mathrm{ha}, 76.9 \%)$ corresponded to the occasionally flooded parts of the floodplain. These areas are currently covered by pastures. Pastures in this region were wetlands, but have now been drained and converted to agriculture lands. In the interfluves only $7.1 \%$ is covered by wetlands (13,149 ha).

\section{Description of Wetland Habitats}

Interfluvial Grassy Shrub Marshes - M

This wetland habitat is located in the interfluves, along the loworder streams and is periodically waterlogged. Interfluvial marshes occur in the small and narrow V-shaped valleys with flat bottom, with size ranges from 0.61 ha to 574.3 ha (mean 25.08 ha, Table 3). This habitat is dominated by grasses, especially Hymenachne amplexicaulis (West Indian Marsh Grass) and Cyperus sp., which have been planted by the ranchers as pasture for livestock. They are locally called "Chuquias".

\section{Riparian Wetlands $-R W$}

This habitat is located along the low order streams (1st-5th order streams) of the interfluve in the elongated and narrow V-shaped valleys and channels with flat bottom. They were 
Fig. 4 Map showing with dots the location (centroids) of the wetlands inventoried and classified in this study. Abbreviations: $\mathrm{M}=$ Interfluvial grassy shrub marshes, RW = Riparian wetlands, $\mathrm{CG}=$ Periodically waterlogged grassy shrub wetland complexes, $\mathrm{CW}=$ Permanently waterlogged woody wetland complexes, $\mathrm{OG}=\mathrm{Per}-$ manently waterlogged grassy shrub oxbow lakes, OW = Permanently waterlogged woody oxbow lakes, $\mathrm{MI}=$ Periodically waterlogged grassy shrub marshes on islands

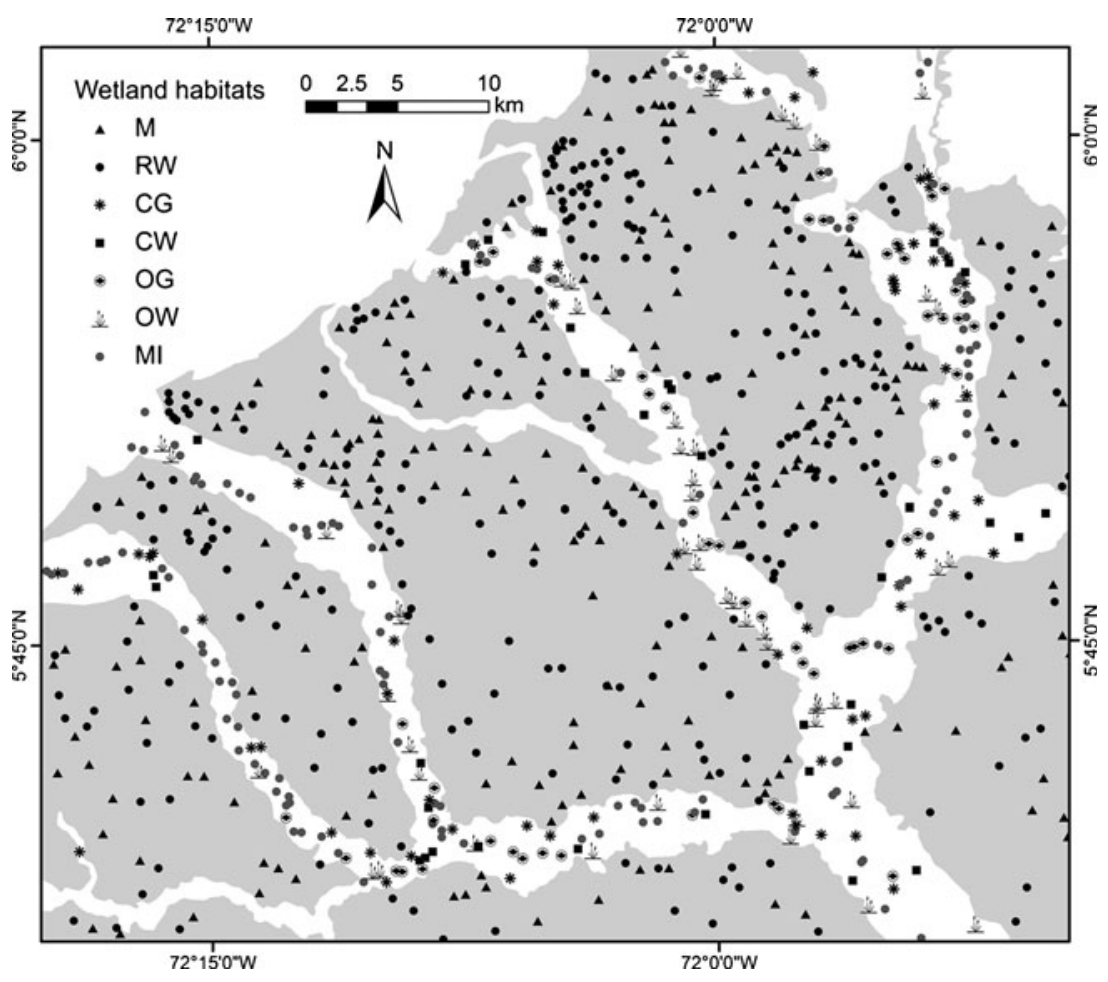

classified as permanently waterlogged; however they may be also seasonally flooded for a short period after the rainfall. The area of the riparian wetlands ranges from 1 ha to 874.8 ha (mean 22.8 ha, Table 3). They are called locally "Bosques riparios" and are floristically diverse. The canopy is open with an average height of $7 \mathrm{~m}$. The dominant plant species are Astrocaryum murumuru, Hyeronima alchorneoides, Mabea nitida, Croton binocularis, and Pollalesta discolor. The understory is dense and diverse with presence of Araceae lianas and ferns such as Adiantum murumuru and A. terminatum.
The category RW also comprises the Mauritia flexuosa palm swamps. The mapping method we used did not allow for us to differentiate between the riparian wetlands and the Mauritia flexuosa palm swamps, and further studies will be needed to separate these categories in the maps. Ground truthing showed clear differences given by structural and floristical features. In the Mauritia flexuosa palm swamps, the canopy is overall dense to semi-open with an average height of 8-10 m and consists - apart from the dominating palm - of species such as Iryanthera tricornis, Pachira aquatica,

Table 3 Summary of the spatial patterns of the seven wetland habitats classified in the Orteguaza River Basin, a tributary of the Caquetá River. Minimal, maximal, mean and standard deviation computed for the wetland area

\begin{tabular}{|c|c|c|c|c|c|c|c|}
\hline Wetland habitat & No. of wetlands & Wetland habitat cover $(\%)$ & Area (ha) & Min & Max & Mean & SD \\
\hline Interfluvial grassy shrub marshes (M) & 238 & 26.6 & $5,969.3$ & 0.6 & 574.3 & 25.1 & 50.7 \\
\hline Riparian wetlands (RW) & 315 & 35.2 & $7,179.9$ & 1.0 & 874.8 & 22.8 & 55.7 \\
\hline $\begin{array}{l}\text { Periodically waterlogged grassy } \\
\text { shrub wetland complexes (CG) }\end{array}$ & 67 & 7.5 & $6,540.9$ & 0.4 & $1,455.6$ & 97.6 & 219.5 \\
\hline $\begin{array}{l}\text { Permanently waterlogged woody } \\
\text { wetland complexes (CW) }\end{array}$ & 34 & 3.8 & $5,199.4$ & 1.6 & $2,399.5$ & 152.9 & 422.4 \\
\hline $\begin{array}{l}\text { Permanently waterlogged grassy } \\
\text { shrub oxbow lakes (OG) }\end{array}$ & 58 & 6.5 & 597.1 & 1.0 & 65.1 & 10.3 & 13.4 \\
\hline $\begin{array}{l}\text { Permanently waterlogged woody } \\
\text { oxbow lakes }(\mathrm{OW})\end{array}$ & 55 & 6.1 & 452.0 & 0.7 & 48.2 & 8.2 & 9.6 \\
\hline $\begin{array}{l}\text { Periodically waterlogged grassy } \\
\text { shrub marshes } \\
\text { on islands (MI) }\end{array}$ & 129 & 14.4 & 546.8 & 0.5 & 54.2 & 4.2 & 6.8 \\
\hline
\end{tabular}


Pachira minor, Zygia latifolia, Spathyphyllum cannaefolium, Urospatha sagittifolia, and Adiantum terminatum. This wetland type is locally called "Cananguchal".

\section{Wetland Complexes (CG and $C W$ )}

This habitat is related to the meander scroll bars, which are generally located on the frequently flooded active river floodplains along the higher-order (6th and higher order) rivers. Their quantity and size increases considerably in the direction towards the South of the Orteguaza River basin, specifically at the confluence of the higher-order rivers (Fragua Chorroso, Pescado, Bodoquero and San Pedro) and the Orteguaza River. The flood amplitudes at the Orteguaza River reach up to $9.70 \mathrm{~m}$ (Fig. 1, plot 1) upstream and $6.64 \mathrm{~m}$ downstream (Fig. 1, plot 3 ), at the San Pedro River up to $6 \mathrm{~m}$ and at the Bodoquero River up to $3.7 \mathrm{~m}$ (Fig. 1, plots 4 and 5). In this category are included:

- Periodically waterlogged grassy shrub wetland complexes (CG)

These wetland habitats are of large size (mean 97.63 ha, min. 0.4 ha, max. 1,455 ha; Table 3). The vegetation is characterized by an open canopy with a maximum height of $7 \mathrm{~m}$. They are floristically less diverse and the dominant plant species are Croton binocularis, Pollalesta discolor, Inga gracilior and Siparuna guianensis. The understory is open and characterized by shrubs with associations of Tournefortia cuspidata, Clidemia hirta and grasses such as Andropogon bicornis. Locally these wetlands are called as "pantanos".

- Permanently waterlogged woody wetland complexes (CW)

These wetlands are the largest in the study area (mean 153 ha, min. 1.62 ha, max. 2,399 ha; Table 3). The vegetation is characterized by a dense and highly diverse canopy with 7-8 $\mathrm{m}$ of average height and consists of species such as Hyeronima alchorneoides, Inga nobilis, Astrocaryum murumuru, Euterpe precatoria, Parkia multijuga, Neea divaricata and Diclinanona tessmannii. The understory is also dense and diverse with species of Montrichardia linifera and Cyathea pungens. The open water surfaces of the wetlands are densely colonized by macrophytes, e.g., Urospatha sagittifolia or the aquatic grass Becquerelia cymosa. These wetland complexes are called "bosques inundables" (floodplain forests).

\section{Oxbow Lakes (OG and $O W)$}

The oxbow lakes, which are called locally "madre viejas" or "lagunas", are especially located at the confluences of the Orteguaza, Pescado, Bodoquero, San Pedro and Hacha Rivers. The flood amplitude at the Hacha River reaches up to $3.7 \mathrm{~m}$ (Fig. 1, plot 6). This category includes two habitat classes according to the predominant vegetation type in their fringes:

- Permanently waterlogged grassy shrub oxbow lakes - OG

These wetlands are characterized by monocotyledoneous species of Montrichardia linifera and Calathea lutea. Structurally they are characterized by an open canopy with a maximum height of $4 \mathrm{~m}$ and a homogeneous open understory. Their size ranges from approximately 1 ha to 65 ha (mean 10.3 ha, Table 3).

- Permanently waterlogged woody oxbow lakes - OW

The vegetation of these wetlands consists of a dense overstory with medium size species (6 to $7 \mathrm{~m}$ ) of Cecropia distachya, Sapium glandulosum, Guarea kunthian, Inga cayennensis, Miconia trinervia, Annona sp., Abarema jupunba, Euterpe precatoria, Zygia latifolia and Miconia tomentos. The understory is sparse with species of Hedychium coronarium and Senna reticulata. Their size ranges from 0.7 ha to 48.2 ha (mean 8.22 ha, Table 3).

\section{Periodically Waterlogged Grassy Shrub Marshes} on Islands - MI

The islands in the study area are characterized by the presence of periodically waterlogged marshes, which are predominantly covered by grassy shrub coverage, with low species diversity due to high anthropogenic intervention. The local ranchers have converted most of these marshes to pasture and have planted non-native species like Desmodium adscencens, Cyperus luzulae, Cyperus odoratus and Hymenachne amplexicaulis (West Indian Marsh Grass) as fodder and Zygia cataractae trees to provide shade for their livestock. Islands size ranges from 0.54 ha to 54.2 ha (mean 4.24 ha, Table 3).

\section{Water Chemistry}

By comparing our results of water chemistry with the existing water parameters previously reported for Amazonia (Sioli 1950; Junk and Furch 1985), we found that black water type is the most prevalent for all wetlands, followed by the clear water type present in all higher-order streams (Orteguaza, Pescado, Bodoquero, Fragua-Chorroso, and Hacha Rivers). In general, the water chemistry of the wetlands showed low concentration of dissolved solids (7-29.2 $\left.\mu \mathrm{S} . \mathrm{cm}^{-1}\right)$, low oxygen concentrations $(0.9-6.82 \mathrm{mg} / \mathrm{l})$, slight tendency towards acidity (4.7-6.7) and high transparency (Secchi disk depth up to $1.5 \mathrm{~m}$ ). 


\section{Discussion}

Our results confirm that the combination of remote sensing and field validation is a powerful method for wetland mapping and can be applied for wetland classification at the regional level (Ozesmi and Bauer 2002; Rebelo et al. 2009). This conclusion is supported by the multidimensional approach we applied, where we analyzed the physiographic units and the landforms where the wetlands may occur, the regime of the water among two different time periods, the water type and the dominant vegetation associated with the wetlands. Such conceptualization stems directly from the more traditional wetland definition (Cowardin et al. 1979; Mitsch and Gosselink 2000) and ensures that the remotely mapped patches were active wetlands in the first place.

In this study, we give the first estimates of wetland area, number and diversity for the Amazonian Piedmont in the Caquetá region of Colombia. The geomorphologic and vegetation features of the landscape outline different types of wetland habitats, which we classified into 7 classes. We achieved an acceptable level of accuracy for the wetland habitat classification, indicated by an overall accuracy of $77.8 \%$ and a Khat estimate of 0.72 based on the 2002 sample of 18 wetlands (Table 2). In the sample of 2012, 10 years after the images used for classification were recorded, we found most disagreements in the classification accuracy between grassy marshes and woody riparian wetlands, which were the habitats most likely affected by human deforestation and natural regeneration of vegetation (Table 2). The other wetland habitats were well classified as indicated by high values of producer and user accuracy (Table 2).

All the 7 wetland habitat classes in our study are compatible with the wetland types described by Cowardin et al. (1979) and Scott (1989). Importantly, our results encourage the use of the dominant floristic groups for the determination of the name of the wetland classes, as suggested for South America by different authors (Junk 1993; Clausen et al. 2006; Junk et al. 2011; Nunes da Cunha and Junk 2011). This approach complies with the local wetland names and their descriptors at the regional scale, which is essential for conservation purposes (Finlayson and van der Valk 1995; MacKay et al. 2009) and for sustainable management (Wantzen et al. 2008). The wetland types found in our (locally restricted) inventory are consistent with those defined by the classification scheme of Junk et al. (2011), who have summarized empirical data on a much wider spatial scale for the Amazonian lowlands. In both studies, the wetlands found in the lower end of the altitudinal gradient in the Andean alluvial deposits are characterized by a monomodal flood pulse, influencing both their morphology and water chemistry, whereas the wetlands found in the interfluves are characterized by polymodal flood pulses.

Methodologically, our system has parallel features with the classification schemes for Canada (Zoltai and Vitt 1995; Warner and Rubec 1997), especially with respect to the hydro-geomorphic attribute, where the landform is the starting element for wetland identification at the patch level. This attribute also provides key knowledge on the relief and hydrology prevailing in the wetlands, both of which are important aspects for determining the source, storage and transport of the water (Brinson 1993; Bedford 1996).

Our results show that geomorphic and vegetation attributes are reliable attributes in differentiation among wetland types. Main inconsistencies in forest species discrimination occurred due to the low spatial resolution of the satellite images (pixel size: $30 \mathrm{~m}$ ). This was clearly shown for the permanent swamps dominated by woody vegetation (Riparian wetlands), which were classified under a single vegetation class (woody). However, ground validation revealed two distinct floristic and structural groups mixed in the same class. It was essential to describe both types separately due to their high representativeness and because of their importance in the functioning of the streams and other aquatic ecosystems in the region. Such problems and other research questions related to wetland connectivity, landscape configuration, delineation and characterization, can be avoided with higher quality images (Frazier et al. 2012).

Wetlands are intensively used for agriculture worldwide. The Amazonian Piedmont in Colombia is a region in which the natural land cover has been severely fragmented and transformed to agriculture during the last century, mainly for cattle production, with little consideration for the preservation of the natural coverage. The ecosystem services provided by wetlands, specifically the provisioning of water and high productivity, bring wetlands more and more into reach of agricultural use during the process of intensification of land use. This development is often detrimental for the maintenance of these services and for the organisms that provide them. Apart from their short-term use for irrigation and fodder production, wetlands offer important functions for biodiversity and carbon storage, especially the small riparian wetlands in agricultural areas of the Neotropics (see Wantzen and Junk 2000 and Wantzen et al. 2012, for reviews). Their small lateral extension makes them specifically vulnerable and makes enforcement of protective laws difficult. Therefore it is very important to communicate the importance of wetlands for the long-term stability of natural and agricultural landscapes to stakeholders.

We found that wetland drainage and conversion to pastures was the main driver for loss of wetlands. Specifically, $76.9 \%$ of the estimated floodplain area within the study area is currently pastures indicating that they have already been drained, logged or otherwise converted for agricultural use. This dramatic decrease of original floodplain area appeals to a significant improvement of political actions to protect the still 
existing floodplains, and to restore at least parts of the degraded areas. Additionally, our vegetation data indicate a high presence of wetland weeds resulting from the intensive agriculture in this region. Planted or invasive weeds such as Desmodium adscencens, Cyperus luzulae, Cyperus odoratus and Hymenachne amplexicaulis (West Indian Marsh Grass) further change the characteristics of these habitats. Therefore, we consider it as a priority to include these remnant patches of wetlands into the focus of conservation efforts. For example the creation of a specific wetland management area in the Orteguaza River catchment, involving local stakeholders, policy-makers and scientists would be ideal to capture what is left of natural wetlands in this region. Likewise, we argue for the technical revision of the existing laws and regulations to conserve and to protect the wetlands in Colombia. There is a need to expand buffer zones around the wetlands based on the area flooded during the highest water level, and according to the order of the streams and the landscape patterns of each type of wetland habitat. This point is of utmost importance, considering firstly that global climate change scenarios predict an increase in extreme flood events, which will likely cause flooded areas more frequently and deeper than before. Secondly, in South America there is a strong pressure from the agro-industrial groups to use wetlands for agricultural production and development of large-scale infrastructure projects. For example, in Brazil, the old forest code defined wetlands as the area flooded during highest water level. Because of pressure from the agro-lobby, the new forest code (Nazareno et al. 2012) is defining wetlands now at the lowest water level, which leaves most of the wetland area unprotected. It has to be expected that the same may happen in other South American countries (W. Junk, Plön, pers. comm.). Moreover, the entire eastern part of Colombia has recently become a focus of interest for mining of metals, which causes additional concern for the conservation of the natural landscape structure including its wetlands (Lasillavacia 2012).

Based on the existing literature, very little is known about the wetlands in the Amazonian Piedmont. One can expect significant differences in wetland landscape patterns between the upper, middle and lower sections of the Amazon catchment. Further studies are needed in order to increase the knowledge about wetlands and their natural resources. A multidimensional research approach, as the one applied here, can provide reliable information for development of better management and recovery plans, which are based on scientific knowledge of each type of wetland habitat.

Acknowledgments This study was funded through Instituto Amazónico de Investigaciones Científicas Sinchi and Ramsar Convention (Small Grants Fund, Project SGF/00/COL/1). Especially we thank EAWAG and DAAD (LFR), and National Institute for Science and Technology in Wetlands (INCT-INAU) (KMW). The comments by the associated editor, two anonymous reviewers, and Kristy Deiner and Luis Cayetano of EAWAG, Dübendorf, Switzerland, helped to improve the manuscript.

\section{References}

Abell R, Thieme ML, Revenga C, Bryer M, Kottelat M, Bogutskaya N, Coad B, Mandrak N, Balderas SC, Bussing W, Stiassny MLJ, Skelton P, Allen GR, Unmack P, Naseka A, Ng R, Sindorf N, Robertson J, Armijo E, Higgins JV, Heibel TJ, Wikramanayake E, Olson D, López HL, Reis RE, Lundberg JG, Sabaj Pérez MH, Petry P (2008) Freshwater ecoregions of the world: a new map of biogeographic units for freshwater biodiversity conservation. BioScience 58:403-414

Adger WN, Luttrell C (2000) Property rights and the utilisation of wetlands. Ecological Economics 35:75-89

Amoros C, Petts GE (eds) (1993) Hydrosystèmes Fluviaux. Macon, Paris Arcila-Niño O, González-León G, Gutiérrez-Rey F, Rodríguez-Salazar A, Salazar-Cardona CA (2000) Caquetá. Construcción de un territorio amazónico en el siglo XX. Pages 25-41. Insituto Amazónico de Investigaciones Científicas Sinchi, Bogotá, Colombia

Bedford BL (1996) The need to define hydrologic equivalence at the landscape scale for freshwater wetland mitigation. Ecological Applications 6:57-68

Bishop YMM, Fienberg SE, Holland PW (1975) Discrete multivariate analysis: theory and practice. M.I.T. Press, Cambridge

Bray JR, Curtis JT (1957) An ordination of the upland forest communities of Southern Wisconsin. Ecological Monographs 27:325-349

Brinson MM (1993) A hydrogeomorphic classification for wetlands. Technical Report WRP-DE-4 U.S. Army Engineer Waterways Experiment Station, Vicksburg, Mississippi, USA

Brinson MM, Malvárez AI (2002) Temperate freshwater wetlands: types, status, and threats. Environmental Conservation 29:115-133

Canevari PID, Blanco DE, Castro G, Bucher EH (eds) (2001) Los Humedales de América del Sur. Una Agenda para la Conservación de la Biodiversidad y las Políticas de Desarrollo. Wetlands International, Netherlands

Carle M (2011) Estimating wetland losses and gains in Coastal North Carolina: 1994-2001. Wetlands 31:1275-1285

Charlton R (2008) Fundamentals of fluvial geomorphology. Routledge, London, New York, Canada

Clausen JC, Ortega IM, Glaude CM, Relyea RA, Garay G, Guineo O (2006) Classification of wetlands in a Patagonian National Park, Chile. Wetlands 26:217-229

Congalton RG (1991) A review of assessing the accuracy of classifications of remotely sensed data. Remote Sensing of Environment $37: 35-46$

Congalton RG (2001) Accuracy assessment and validation of remotely sensed and other spatial information. International Journal of Wildland Fire 10:321-328

Cowardin LM, Carter V, Golet FC, LaRoe ET (1979) Classification of wetlands and deepwater habitats of the United States., U. S. Department of the Interior, Fish and Wildlife Service, Washington, D.C., Washington, DC, USA. FWS/OBS -79/31

Diegues AC (2002) Povos e Águas - Inventário de áreas úmidas brasileiras, NUPAUB-USP, 2ed

Duivenvoorden JF (1996) Patterns of tree species richness in rain forests of the Middle Caqueta Area, Colombia, NW Amazonia. Biotropica 28:142-158

Duque SR, Ruiz JE, Gómez J, Roessler E (1997) Limnologia. In: Codazzi IGA (ed) Zonificación ambiental para el plan colombobrasilero (eje Apaporis - Tabatinga: PAT). Editorial Linotipia, Santafé de Bogotá, Colombia

Eslava J, López V, Olaya O (1986) Los Climas de Colombia. Sistemas de Caldas \& Lang (1918). Atmosfera 5:35-81

ESRI (2011) ArcGIS Desktop: Release 10. Environmental Systems Research Institute, Redlands, CA

Etter A, McAlpine C, Phinn S, Pullar D, Possingham H (2006a) Characterizing a tropical deforestation wave: a dynamic spatial 
analysis of a deforestation hotspot in the Colombian Amazon. Global Change Biology 12:1409-1420

Etter A, McAlpine C, Phinn S, Pullar D, Possingham H (2006b) Unplanned land clearing of Colombian rainforests: spreading like disease? Landscape and Urban Planning 77:240-254

Etter A, McAlpine C, Pullar D, Possingham H (2006c) Modelling the conversion of Colombian lowland ecosystems since 1940: drivers, patterns and rates. Journal of Environmental Management 79:74-87

Finlayson CM, van der Valk AG (1995) Wetland classification and inventory: a summary. Plant Ecology 118:185-192

Frazier PS, Page KJ (2000) Water body detection and delineation with Landsat TM data. Photogrammetric Engineering and Remote Sensing 66:1461-1467

Frazier P, Ryder D, McIntyre E, Stewart M (2012) Understanding riverine habitat inundation patterns: remote sensing tools and techniques. Wetlands 32:225-237

Gentry AH (1992) Tropical forest biodiversity - distributional patterns and their conservational significance. Oikos 63:19-28

Gopal B (2005) Relevance and policy dimensions of research on biodiversity in freshwater ecosystems: a developing country perspective. Hydrobiologia 542:19-21

Gutierrez-Rey F, Acosta-Munoz LE, Salazar-Cardona CA (2003) Perfiles Urbanos en la Amazonia Colombiana: Un Enfoque para el Desarrollo Sostenible. Pages 71-84. Instituto Amazonico de Investigaciones Cientificas Sinchi, Bogota, Colombia

Hui F, Xu B, Huang H, Yu Q, Gong P (2008) Modelling spatialtemporal change of Poyang Lake using multitemporal Landsat imagery. International Journal of Remote Sensing 29:5767-5784

IDEAM (2011) Sistema de informacion nacional ambiental. Instituto de hidrologia, meteorologia y estudios ambientales, Bogota

IGAC (1979) Proyecto Radargrametrico del Amazonas, La Amazonia Colombiana y sus recursos. IGAC-CIAF-Mindefensa, Proradam, Bogota, Colombia

IGAC (1999) Paisajes fisiográficos de Orinoquia - Amazonia (ORAM). Instituto Geográfico Agustín Codazzi Santafé de Bogotá, Colombia

ITC-ILWIS (2005) The Integrated Land and Water Information System. International Institute for Aerospace Survey and Earth Sciences (ITC), Enschede, Netherlands

Jensen JR (2000) Remote sensing of the environment: an earth resource perspective. Prentice-Hall, Upper Saddle River

Junk WJ (1993) Wetlands of tropical South America. Wetlands of the world: inventory, ecology and management. Vol. I:679-739

Junk WJ (2002) Long-term environmental trends and the future of tropical wetlands. Environmental Conservation 29:414-435

Junk WJ, Bayley PB, Sparks RE (1989) The flood pulse concept in riverfloodplain systems. Can Spec Publ Fish Aquat Sci 106:110-127

Junk WJ, Furch K (1985) The physical and chemical properties of Amazonian waters and their relationships with the biota. In: Prance GT, Lovejoy TE (eds) Key Environments Amazonia. Pergamon Press, Oxford, pp 3-17

Junk WJ, Piedade MTF (2004) Status of knowledge, ongoing research, and research needs in Amazonian wetlands. Wetlands Ecology and Management 12:597-609

Junk WJ, Piedade MTF (2005) The Amazon River basin. In: Fraser LH, Keddy PA (eds) The world's largest wetlands: ecology and conservation. Cambridge University Press, Cambridge, p 498

Junk WJ, Piedade MTF, Schöngart J, Cohn-Haft M, Adeney J, Wittmann F (2011) A classification of major naturally-occurring Amazonian lowland wetlands. Wetlands 31:623-640

Lasillavacia (2012) http://www.lasillavacia.com/historia/la-reservaminera-en-la-amazonia-que-el-ministro-de-ambiente-aprobo-sinestudiar-35135. Accessed 12 Sep 2012

Leopold L, Wolman MG, Miller JP (1964) Fluvial processes in geomorphology. W.H. Freeman, San Francisco
MacKay H, Finlayson CM, Fernández-Prieto D, Davidson N, Pritchard D, Rebelo LM (2009) The role of Earth Observation (EO) technologies in supporting implementation of the Ramsar Convention on Wetlands. Journal of Environmental Management 90:2234-2242

Malhi Y, Roberts JT, Betts RA, Killeen TJ, Li W, Nobre CA (2008) Climate change, deforestation, and the fate of the Amazon. Science 319:169-172

Maltby E (2009) The changing wetland paradigm. In: Maltby E, Barker T (eds) The Wetlands Handbook. Wiley-Blackwell, Oxford, pp 3-42

Maltchik L (2003) Three new wetlands inventories in Brazil. Interciencia 28:421-423

Meidinger DV (2000) Protocol for Quality Assurance and Accuracy Assessment of Ecosystem Maps. B.C. Ministry of Forests, Victoria, BC, Canada

Mertes LAK, Dunne T (2008) Effects of tectonism, climate change, and sea-level change on the form and behaviour of the modern Amazon River and its floodplain. John Wiley \& Sons, Ltd

Millenium Ecosystem Assessment (2005) Ecosystems and human well-being: wetlands and water synthesis. World Resources Institute, Washington, DC

Mitsch WJ, Gosselink JG (2000) The value of wetlands: importance of scale and landscape setting. Ecological Economics 35:25-33

Mitsch WJ, Gosselink JG (2007) Wetlands, 4th edn. John Wiley and Sons, Inc., Hoboken

Mitsch WJ, Gosselink JG, Anderson CJ, Zhang L (2009) Wetland ecosystems. Wiley, New York

Myers N, Mittermeier RA, Mittermeier CG, da Fonseca GAB, Kent J (2000) Biodiversity hotspots for conservation priorities. Nature 403:853-858

Naranjo LG (1995) An evaluation of the first inventory of South American wetlands. Plant Ecology 118:125-129

Nazareno AG, Feres JM, de Carvalho D, Sebbenn AM, Lovejoy TE, Laurance WF (2012) Serious new threat to brazilian forests. Conservation Biology 26:5-6

Neiff JJ (2001) Humedales de la Argentina: sinopsis, problemas y perspectivas futuras. In: Cirelli AF (ed) El agua en Iberoamérica. Funciones de los humedales, calidad de vida y agua segura. CYTED. Programa Iberoamericano de Ciencia y Tecnología para el Desarrollo, pp 83-112

Nunes da Cunha C, Junk WJ (2011) A preliminary classification of habitats of the Pantanal of Mato Grosso and Mato Grosso do Sul, and its relation to national and international wetland classification systems. In: Junk WJ, da Silva CJ, Nunes da Cunha C, Wantzen KM (eds) The Pantanal: Ecology, Biodiversity and Sustainble Management of a Large Neotropical Seasonal Wetland. Pensoft publishers Sofia-Moscow, pp 127-141

Odum HT (1983) Systems ecology: an introduction. John Wiley, NY

Ozesmi SL, Bauer ME (2002) Satellite remote sensing of wetlands. Wetlands Ecology and Management 10:381-402

Polunin NVC, Gopal B, Graham NAJ, Hall S, Ittekkot V, Mühlig-Hofmann A (2008) Trends and global prospects of the Earth's aquatic ecosystems. In: Pulunin NVC (ed) Aquatic ecosystems: trends and global prospects. Cambridge University Press, Cambridge, p 512, New York

Prance GT (1982) A review of the phytogeographic evidences for pleistocene climate changes in the neotropics. Annals of the Missouri Botanical Garden 69:594-624

Ramsar (2006) The Ramsar Convention Manual: a guide to the Convention on Wetlands (Ramsar, Iran, 1971), 4th ed. Ramsar Convention Secretariat, Gland, Switzerland

Rebelo LM, Finlayson CM, Nagabhatla N (2009) Remote sensing and GIS for wetland inventory, mapping and change analysis. Journal of Environmental Management 90:2144-2153

Saldarriaga JG, van der Hammen T (eds) (1993) Aspectos ambientales para el ordenamienmto territorial del occidente del departemento del Caquetá. IGAC, Tropenbos, Bogota, Colombia 
Scott DA (1989) Design of wetland data sheet for database on Ramsar Sites. Photocopied report to Ramsar Bureau. Gland, Switzerland

Scott DA, Carbonell M (eds) (1986) A directory of neotropical wetlands. IUCN, Gland, Switzerland

Semeniuk CA, Semeniuk V (1995) A geomorphic approach to global classification for inland wetlands. Plant Ecology 118:103-124

Sioli H (1950) Das wasser im Amazonasgebiet. Forsch. Fortschr 274 280

Sioli H (ed) (1984) The Amazon: Limnology and landscape ecology of a mighty tropical river and its basin. Dr. W. Junk Publishers, Dordrecht Netherlands and Boston and Hingham

Story M, Congalton RG (1986) Accuracy assessment-A users perspective. Photogrammetric Engineering and Remote Sensing 52:397-399

Strahler AN (1952) Dynamic basis of geomorphology. Geological Society of America Bulletin 63:923

Turner RK, van den Bergh JCJM, Söderqvist T, Barendregt A, van der Straaten J, Maltby E, van Ierland EC (2000) Ecological-economic analysis of wetlands: scientific integration for management and policy. Ecological Economics 35:7-23

Villota H (1992) El sistema CIAF de clasificación fisiográfica del terreno. Revista CIAF 13:55-70

Wantzen KM, Couto EG, Mund EE, Amorim RSS, Siqueira A, Tielbörger K, Seifan M (2012) Soil carbon stocks in stream-valley-ecosystems in the Brazilian Cerrado agroscape. Agriculture, Ecosystems and Environment 151:70-79

Wantzen KM, Da Cunha CN, Junk WJ, Girard P, Rossetto OC, Penha JM, Couto EG, Becker M, Priante G, Tomas WM, Santos SA, Marta J, Domingos I, Sonoda F, Curvo M, Callil C (2008) Towards a sustainable management concept for ecosystem services of the Pantanal wetland. Ecohydrology and Hydrobiology 8:115-138

Wantzen KM, Junk WJ (2000) The importance of stream-wetlandsystems for biodiversity: a tropical perspective. In: Gopal B, Junk WJ, Davies JA (eds) Biodiversity in Wetlands: assessment, function and conservation. Backhuys, Leiden, pp 11-34

Warner BG, Rubec CDA (eds) (1997) The Canadian Wetland Classification System. Wetlands 2Research Centre, University of Waterloo, Waterloo, Ontario

Wiens JA (2002) Riverine landscapes: taking landscape ecology into the water. Freshwater Biology 47:501-515

Zedler JB, Kercher S (2005) Wetland resources: status, trends, ecosystem services, and restorability. Annual Review of Environment and Resources 30:39-74

Zoltai SC, Vitt DH (1995) Canadian wetlands: environmental gradients and classification. Plant Ecology 118:131-137

Zuluaga G (2008) Conservation of the Biological and Cultural Diversity of the Colombian Amazon Piedmont: Dr. Schultes' Legacy. Ethnobotany Research \& Applications; Vol 3 (2005) 